\title{
Bioengineering Global Health: Design and Implementation of a Summer Day Camp for High School Students
}

\section{Dr. Dianne Grayce Hendricks, University of Washington}

Dr. Dianne G. Hendricks is a Lecturer in the Department of Bioengineering at the University of Washington. She earned a BS in Molecular Biology at the University of Texas at Austin and a PhD in Genetics at Duke University. Dr. Hendricks' teaching interests at the University of Washington include developing and teaching introductory and honors courses in bioengineering, tissue and protein engineering lab courses, and capstone projects. She is committed to creating opportunities for undergraduates to engage in K-12 education and outreach. At both Duke University and the University of Washington, Dr. Hendricks has developed and taught summer camp curricula for middle school and high school students.

\section{Ms. Lucy L. Pick, University of Washington}

Lucy L. Pick is Curriculum Coordinator for the Department of Bioengineering at the University of Washington where she serves as Bioengineering Summer Camp Director. Pick received a Bachelor of Arts in Social Science from Western Oregon University and is pursuing a graduate certificate in Biomedical Regulatory Affairs from the University of Washington. Pick's interests include educational outreach, STEM education policy, and regulatory affairs.

\section{Dr. Alyssa Catherine Taylor, University of Washington}

Alyssa C. Taylor is a lecturer in the Department of Bioengineering at the University of Washington. She received a B.S. in biological systems engineering at the University of California, Davis, and a Ph.D. in biomedical engineering at the University of Virginia. Taylor's teaching activities are focused on developing and teaching core introductory courses and technical labs for bioengineering undergraduates, as well as coordinating the capstone design sequence for the BIOE Department at the University of Washington. Taylor currently pursues educational research and continuous improvement activities, with the ultimate goal of optimizing bioengineering curriculum design and student learning outcomes. 


\title{
Bioengineering Global Health: Design and Implementation of a Summer Day Camp for High School Students
}

\begin{abstract}
$\underline{\text { Abstract }}$
Summer camps present opportunities for students to expand their knowledge of science and engineering principles and applications, acquire hands-on experience in laboratory techniques, and increase interest in pursuing college degrees and careers in science and engineering. Although many engineering summer camps for high school students are offered throughout the country, few are focused specifically on bioengineering.

In this paper, we present our approach to designing a summer day camp for rising $9^{\text {th }}$ and $10^{\text {th }}$ graders that is unique in its focus on bioengineering and use of a global health theme. We chose global health because it is an intriguing topic that appeals to students from all backgrounds and is accessible to students with variable previous exposure to science and engineering topics. Furthermore, global health applications clearly demonstrate important bioengineering design principles and showcase the positive impact bioengineers make on society. These considerations are especially important for students from groups that are under-represented in science and engineering. To our knowledge, this is the only currently available summer camp in which high school students explore bioengineering in the context of global health.

The curriculum for the one-week program consisted of short lectures, team-based problem solving activities, research lab tours, and an interactive information session with current bioengineering undergraduates at the University of Washington (UW). Topics included the engineering design process, molecular biology of infectious disease, synthetic biology, drug delivery in HIV treatment, and low-cost point-of-care diagnostics. Students were encouraged to have informal conversations with undergraduate and graduate student guest instructors during lunch. As a culminating end-of-camp activity, students worked in teams to design solutions to current problems in global health and presented their projects to peers and guests.
\end{abstract}

Students provided both quantitative and qualitative assessment of the camp through pre- and post-camp surveys. Student assessment data indicate that the camp was effective in increasing students' self-assessed knowledge about science and engineering and the bioengineering field, and the camp increased the participants' desire to attend college at the host institution in the future. Students enjoyed the team project of designing a solution to a problem in global health. As student assessment indicates that the camp was an enjoyable and effective learning experience, this camp will serve as a model for future offerings.

\section{Introduction}

Summer outreach camps provide pre-college students with the opportunities to explore a wide variety of fields and to investigate potential college major and career options. These programs help expose and attract students to science and engineering disciplines and can serve as effective recruiting tools. Previously implemented summer camps focused on science and engineering fields have been shown to be successful in significantly enhancing student recruitment, 
understanding of the field, and motivation to pursue an engineering degree ${ }^{1,2}$. Additionally, summer programs can support achievement of educational goals, including helping students develop specific scientific content knowledge ${ }^{3}$.

Countless engineering-focused summer camps exist throughout the country, granting students exposure to multiple engineering fields. Summer camps that are focused solely on bioengineering or biomedical engineering, however, are more limited. Those that have been implemented thus far have been shown to be very successful. Although it is not feasible to summarize all of the relevant camps, one example is a bioengineering summer day camp hosted by the University of Illinois-Chicago. Their program increased student familiarity with bioengineering, possible job opportunities in bioengineering, and their interest in pursuing a bioengineering college major and career ${ }^{4}$. At Western New England College, a previously offered biomedical engineering summer program increased student understanding of both the wide variety of subspecialties in the field as well as the educational opportunities available in biomedical engineering at the host institution ${ }^{5}$.

Among the bioengineering camps offered, some are focused on a particular area of bioengineering. For instance, the University of Pittsburgh offers a week-long camp focused on tissue engineering for both middle school and high school students ${ }^{6}$. Columbia University hosts a biomedical engineering summer program for rising $11^{\text {th }} / 12^{\text {th }}$ graders or incoming freshmen which emphasizes cell responses to physical stimuli ${ }^{7}$. However, to the best of our knowledge, no summer camp is available for pre-college students to explore bioengineering in the context of global health applications, although Rice University offers multiple opportunities for high school students to learn about global health issues and to gain experience in developing global health technologies through its Beyond Traditional Borders high school curriculum program ${ }^{8}$.

University of Southern California offers a two-week experience entitled "Global Health and Disease" which introduces students to important global health issues ${ }^{9}$, but we were motivated to create a camp that approached global health topics from a bioengineering perspective.

We chose the theme of global health for our camp for three main reasons. First, the bioengineering department at UW is especially strong in global health research and Seattle is home to many organizations involved in global health, allowing us to give the students a strong first-hand introduction to many aspects of global health research.

Second, applications in global health demonstrate bioengineering design principles in a manner that is clear to high school students. Problems and solutions in global health, such as prevention of infectious disease by vaccination, are familiar to students from their own experiences and/or coverage in the media. Criteria that are familiar to high school age students such as safety, cost, sustainability, and user-friendliness are critical in global health solutions.

Third, global health is an intriguing topic that appeals to students from all backgrounds and is accessible to students with variable previous exposure to science and engineering topics. Making the camp curriculum interesting and accessible to students from diverse backgrounds was an important consideration as we designed the camp. Applications in global health clearly demonstrate the human element of engineering and how bioengineers have a positive impact on society. These considerations are especially important for students from groups that are under- 
represented in science and engineering. A recent study by the National Academy of Engineering showed that girls and other under-represented minorities are more likely to be interested in engineering when the "helping" or "nurturing" aspects of engineering are emphasized".

Thus, to provide the unique opportunity for high school students from diverse backgrounds to gain exposure to the bioengineering field using the context of global health, at the UW we designed and implemented a summer day camp for rising $9^{\text {th }}$ and $10^{\text {th }}$ graders. The objectives of the summer camp were to:

1) Increase student understanding of science and engineering concepts

2) Increase student knowledge of the field of bioengineering

3) Engage students in investigating how bioengineers help society

4) Provide students an opportunity to apply the engineering design process in a team project

5) Increase student confidence in solving bioengineering problems

6) Foster student interest in taking science and engineering classes in high school and college

7) Cultivate interest in attending UW by exposing students to aspects of the college experience through interaction with undergraduate bioengineering students

8) Hone teamwork and communication skills through small group activities and final team project

\section{Participants}

Beginning in January 2014, information about the week-long camp to be held in July 2014 was mailed to 95 Seattle area public and private schools and education-focused community organizations. In addition, the camp was advertised through flyers available at Engineering Discovery Days, a two-day UW College of Engineering event in April 2014 that was open to the community and was attended by many local school groups.

The camp application materials stated that rising $9^{\text {th }}$ and $10^{\text {th }}$ grade students who were interested in bioengineering and/or global health were encouraged to apply. The application consisted of a 300 -word essay describing the applicant's interest in bioengineering and a letter of recommendation from a middle or high school science teacher. Applicants were evaluated primarily on their level of interest in bioengineering, especially in the area of global health, conveyed in the essay. However, we carefully considered information in the teacher recommendation about the potential impact of the camp on the student and personal attributes of the student such as intellectual curiosity, maturity, and ability to work well with other students.

The application required information about the student such as age, gender, grade, and school attended. Information about ethnicity was optional, but many applicants provided this information. Although not the primary criteria, we considered these factors in admission. We admitted more rising $10^{\text {th }}$ grade students than $9^{\text {th }}$ grade students, reasoning that the younger students were eligible to apply the following year.

A total of 36 students submitted complete applications, and 24 students were admitted to the camp. There were 14 female and 10 male students, and 8 rising $9^{\text {th }}$ grade and 16 rising $10^{\text {th }}$ grade students. 
Upon admission to the camp, students paid $\$ 500$ tuition, which covered all program materials and daily lunch and snacks. Full tuition scholarships for three students were available through a donation from an alumnus working at a national biotechnology firm. Students who qualified for free/reduced meals according to the household financial criteria of the Seattle/King County Public School System were eligible for scholarships. In order to receive a scholarship, a student's family contacted the camp director with their request (formal documentation of financial information was not required).

Only local students were selected for admission to the camp, as we plan to follow up with these students in the future and desire to use the summer camp program to build relationships with local high schools for possible mentoring and outreach opportunities.

\section{Instructors}

A core instructional group of the camp director (staff program coordinator) and two instructors (faculty lecturer and graduate student) gave introductory lectures and led activities throughout the camp. In addition to the core instructors, guest instructors (including faculty, undergraduate and graduate students, and research scientists) facilitated activities, demonstrations, and lab tours. This instructor model allowed continuity for the students while bringing in experts for the various modules.

\section{Program Logistics}

The one-week camp was held from 9:00 am to 4:00 pm Monday through Friday on the UW campus. Each day was divided into morning and afternoon sessions of approximately 2.5 hours. At the end of the day, the students reflected on what they learned and participated in small group discussions. A brief schedule of the program is shown in Table 1.

Throughout the camp, students were exposed to "college life" at UW. During the 1.5-hour lunch break, students and camp staff walked through campus to the student center and purchased lunch with UW meal cards provided by the camp. Students were encouraged to have informal conversations with camp staff and guest instructors. On the last day of camp, students learned about the undergraduate experience in the bioengineering department at UW through presentations of research projects and a question/answer session with current undergraduates.

Family and friends were invited to the end-of-camp activities consisting of student presentations of their culminating project followed by a reception.

For daily camp activities, we utilized undergraduate teaching lab space in the bioengineering department at UW including a small lecture room, wet lab space, and computing facilities. The availability of space limited camp enrollment to 24 participants. 
Table 1. Schedule of Activities

\begin{tabular}{|c|c|c|c|c|c|}
\hline & MONDAY & TUESDAY & WEDNESDAY & THURSDAY & FRIDAY \\
\hline $\begin{array}{l}\text { 9:00- } \\
11: 30\end{array}$ & $\begin{array}{l}\text { Orientation/Rules } \\
\text { Icebreaker Games } \\
\text { What is BIOE? } \\
\text { What is Global } \\
\text { Health? } \\
\text { Bioengineering } \\
\text { Design Game }\end{array}$ & $\begin{array}{l}\text { Global health } \\
\text { context of } \\
\text { HIV } \\
\text { Activity: } \\
\text { Model of } \\
\text { Cellular HIV } \\
\text { Infection }\end{array}$ & $\begin{array}{l}\text { Introduction } \\
\text { Rules of field trip } \\
\text { 10:00 leave } \\
\text { campus for } \\
\text { field trip }\end{array}$ & $\begin{array}{l}\text { Tours of } \\
\text { Research Labs } \\
\text { Disease } \\
\text { Diagnostics } \\
\text { - Microfluidics } \\
\text { - Point-of-care }\end{array}$ & $\begin{array}{l}\text { Presentations by } \\
\text { recent } \\
\text { graduates: } \\
\text { Senior Capstone } \\
\text { Design Projects } \\
\\
\text { Undergraduate } \\
\text { Panel Info } \\
\text { Session }\end{array}$ \\
\hline $\begin{array}{l}11: 30- \\
1: 00\end{array}$ & Lunch & Lunch & Lunch & Lunch & Lunch \\
\hline $1: 00-3: 30$ & $\begin{array}{l}\text { Central Dogma of } \\
\text { Biology } \\
\text { Molecular Biology } \\
\text { of Infectious } \\
\text { Disease }\end{array}$ & $\begin{array}{l}\text { Cellular } \\
\text { Targets for } \\
\text { HIV } \\
\text { Treatment } \\
\text { Engineering } \\
\text { Design Lab: } \\
\text { Drug Delivery }\end{array}$ & $\begin{array}{l}\text { 2:00 return to } \\
\text { campus } \\
\text { Synthetic } \\
\text { Biology } \\
\text { Begin working } \\
\text { on presentations }\end{array}$ & $\begin{array}{l}\text { Work on } \\
\text { presentations in } \\
\text { computer lab }\end{array}$ & $\begin{array}{l}1: 00 \\
\text { Welcome and } \\
\text { Student } \\
\text { Presentations } \\
2: 30 \\
\text { Reception }\end{array}$ \\
\hline $3: 30-3: 45$ & $\begin{array}{l}\text { Reflection and } \\
\text { Clean-up }\end{array}$ & $\begin{array}{l}\text { Reflection and } \\
\text { Clean-up }\end{array}$ & $\begin{array}{l}\text { Reflection and } \\
\text { Clean-up }\end{array}$ & $\begin{array}{l}\text { Reflection and } \\
\text { Clean-up }\end{array}$ & \\
\hline
\end{tabular}

\section{Curriculum}

The students experienced hands-on lab activities and demonstrations related to current research in the bioengineering department at UW as well as lab tours. The curriculum was designed with an emphasis on project-based activities, working in teams, and communicating ideas and results through short oral presentations.

What Is Bioengineering?

This 30 minute lecture provided an overview of bioengineering research areas, demonstrated the interdisciplinary nature of bioengineering, and showcased several real-world bioengineering solutions. This introduction included a broad overview of the undergraduate admissions process for the Bioengineering department at UW.

What is Global Health?

The introduction to global health focused on special considerations for designing and implementing bioengineering solutions in low resource settings, including political/cultural influences, shortage of healthcare workers, lack of infrastructure, and the high burden of 
infectious disease. Several examples of bioengineering solutions developed for low-resource settings were discussed, including an infant incubator and a water sanitation system.

\section{Bioengineering Design Game}

After a brief introductory lecture on the steps in the engineering design process, students were given the challenge of designing a better bandage for an application of their choice. Each group of students defined the need/problem, designed a solution, pitched their solution to potential investors, purchased materials from a supply store, tested their prototype, and demonstrated their prototype. At the end of the activity, it was revealed that the supply store had charged each group different prices for materials to simulate different allocation of resources. The students engaged in discussion of the technical aspects of their designs as well as the financial, ethical, and societal considerations that must be considered when designing solutions in global health.

\section{Central Dogma of Biology}

This module introduced basic principles of genetics and the mechanisms of DNA replication, transcription of DNA to messenger RNA, and translation of mRNA to protein. Students participated in a "Double Helix Race" to build DNA structures from colored blocks. The purpose of this unit was to provide background knowledge for the HIV and synthetic biology modules.

\section{Molecular Biology of Infectious Disease}

This short lecture introduced students to the burden of infectious disease around the world. Students learned about the mechanisms of transmission of infectious diseases (such as malaria, tuberculosis, and HIV) and current efforts to prevent, diagnose, and treat infection. Students brainstormed about factors that bioengineers must consider when implementing such efforts in low resource settings.

HIV: Global Health Context, Infection Model, Targets for Treatment, and Drug Delivery This module included a brief introductory lecture, a game in which students modeled the cellular process of HIV infection, and hands-on lab activities to demonstrate three different modes of drug delivery. First, students learned about the prevalence of HIV around the world and ongoing efforts to prevent and treat HIV infection in a global health context. (To ensure that the material was age-appropriate, activities focused on preventing mother-to-child transmission and treatment of children infected with HIV.) Students played a board game that simulated the cellular process of HIV infection under different conditions (e.g., normal vs. mutated virus, or with vs. without drug treatment) and brainstormed how drugs could target different steps of the infection. The students then participated in three different hands-on lab activities in which they made models of different platforms of drug delivery: alginate beads simulating nanoparticles (injectable), hydrogels (oral), and micro-spun nanofibers (transdermal).

\section{Gates Foundation Visitor Center Field Trip}

To help spark their interest in designing solutions to problems in global health, students took a field trip to the Gates Foundation Visitor Center. In the 90-minute tour, students learned of several solutions to global health problems that have been developed and implemented by the Gates Foundation, explored the advantages and disadvantages of different solutions, and brainstormed solutions to other needs. 
Introduction to Synthetic Biology

Students learned about the field of synthetic biology, including a case study of the production of a synthetic anti-malaria drug, artemisinin, by genetically engineered microbes. Student teams brainstormed solutions in synthetic biology to a global health need of their choice, and then presented their ideas. In addition, students viewed Petri plates of genetically engineered bacteria that expressed fluorescent proteins under UV light.

Point-of-Care Diagnostics Using Microfluidics

This module included a brief introductory lecture, hands-on activity in which students tested different microfluidic devices, and demonstrations. In a brief lecture, students learned the importance of low-cost, easy-to-use, point-of-care diagnostics in low resource settings and why paper-based diagnostics are ideal for use in such settings. In an inquiry-based activity, students determined the requirements for a successful microfluidic device (i.e., design requirements to deliver the different colored liquids, simulating diagnostic chemical reagents, to the sample pad in the correct order). Students added colored water to three different designs of pre-made folded card-style microfluidic devices in which the capillary action of the paper pulled the fluids through the device. By observing the flow of different colored liquids through the device, students observed that one design successfully delivered the fluids in the proper sequence, but two of the three device designs failed. The students discussed why they thought each microfluidic device design failed or succeeded. Finally, students participated in demonstrations of controlling fluid flow by tuning the microfluidic resonant frequency (by singing the correct note to make fluid in a microchannel flow) and detecting changes in fluid properties by monitoring the shift in resonant frequency of example fluids.

Culminating End-of-Camp Project

Students formed small groups (3-4 students) for the end-of-camp project. Students were asked to identify a need in global health and design a bioengineering solution. Each group prepared a 10minute Power Point presentation. Although students did not need to build a prototype, students were asked to describe how they would proceed through the engineering design process. Students were asked specifically to address the societal impact of their solution.

\section{Program Assessment}

\section{Methods}

The success of this program was evaluated using student surveys. Using methodology approved by the Institutional Review Board of the host institution, students were given the opportunity to complete both pre- and post-camp surveys (see Appendices). The students were informed that completion of the surveys was voluntary, there would be no negative consequence for not completing the survey, the survey results were anonymous, the surveys would not be reviewed until after camp completion, and results would be used for program improvement purposes.

The data were collected in a manner that promoted accuracy and confidentiality. Before administering the pre-camp survey, each camper selected an envelope containing both surveys. The envelope and enclosed surveys were pre-numbered with the same identifier (numbers 1 24). The instructor asked each student to write his/her favorite food, color, and animal on the envelope in lieu of any other identifying information. This guaranteed anonymity/confidentiality 
but did not require students to remember or write down his/her survey number, thus allowing each student to accurately identify his/her envelope at the end of camp for completion of the post-camp survey. As the comparison between the pre- and post-camp data was important, the pre- and post-camp surveys were printed on different colored paper.

All 24 participants completed both the pre- and post-camp surveys. The pre-camp survey asked students to indicate the reason they attended the camp and one challenge they identified in applying to college. In addition, the pre-camp survey asked for descriptive information about the student (such as grade in high school in the upcoming academic year, primary language spoken at home, gender, whether a family member had attended college, and ethnicity). The post-camp survey asked several questions regarding the effectiveness of the program and solicited feedback for improvements for the camp in the future.

The pre- and post-camp surveys both contained an identical set of 16 statements that students rated on a Likert scale of $0-4(0=$ strongly disagree, $1=$ disagree, $2=$ neutral or unsure, $3=$ agree, $4=$ strongly agree). For statistical analysis, comparisons of pre- and post-camp paired data were conducted using the Wilcoxon signed-rank test. Statistical significance was accepted at a p-value of 0.05 . For each statement, we investigated whether differences existed pre- vs. postcamp for all 24 students, for females only, and for males only with regards to impact of the camp on various outcomes.

\section{Quantitative Results}

Of the 16 statements tested, the greatest increase in score was for the statement "I know a lot about the field of bioengineering" $(\mathrm{p}<0.001)$ (Figure 1).

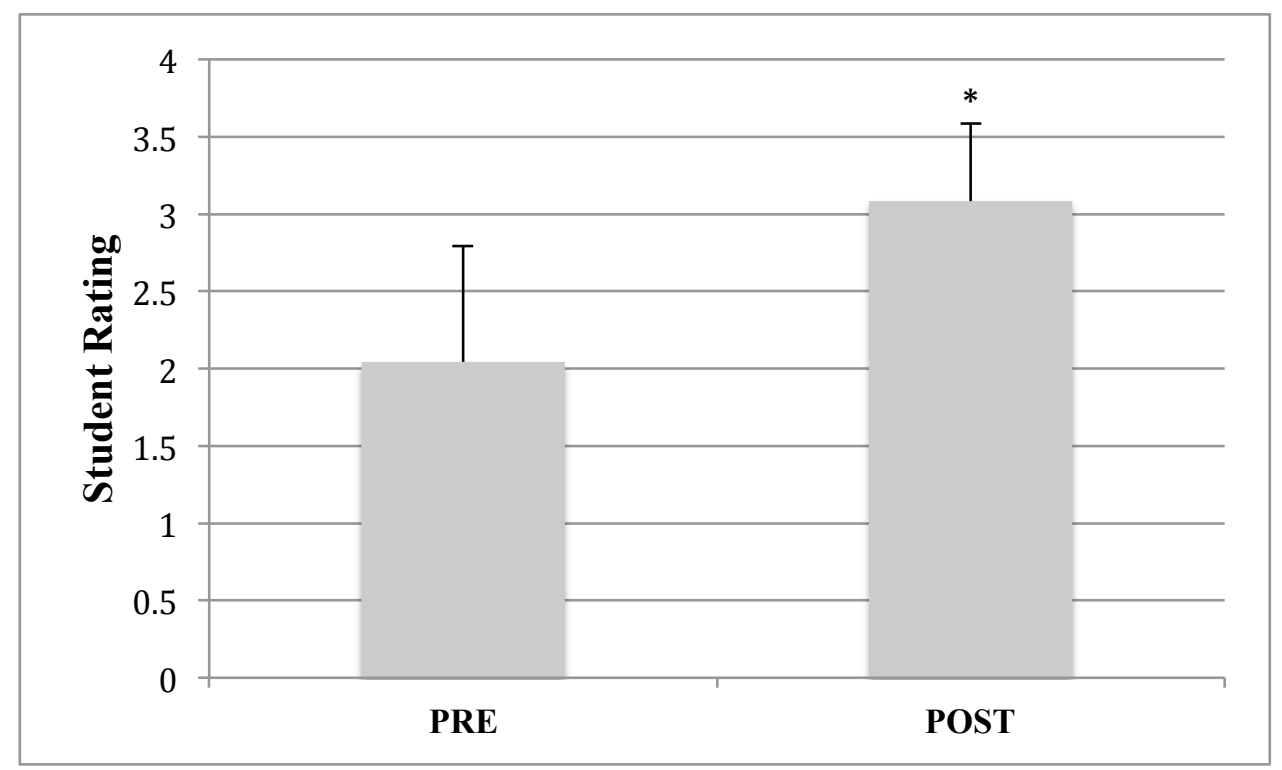

Figure 1. Student rating of statement "I know a lot about the field of bioengineering" on Likert scale $(0=$ strongly disagree, $1=$ disagree, $2=$ neutral or unsure, $3=$ agree, $4=$ strongly agree) in pre-vs. post-camp surveys. Results shown as mean + standard deviation. ${ }^{*} \mathrm{p}<0.001$. 
For the statement "I know a lot about the field of bioengineering," the increase was significant in both females $(p<0.001)$ and males $(p=0.031)$ (data not shown). We note that $12 / 14$ females reported an increase of at least one whole Likert number, whereas 6/10 males reported an increase of at least one whole Likert number (two male students reported an increase of 1 Likert number, three male students reported an increase of 2 Likert numbers, and one male student reported an increase of 3 Likert numbers).

Comparing pre- to post-survey results, students' scores increased significantly for the statement "I know a lot about science and engineering" $(\mathrm{p}<0.001)$ (Figure 2).

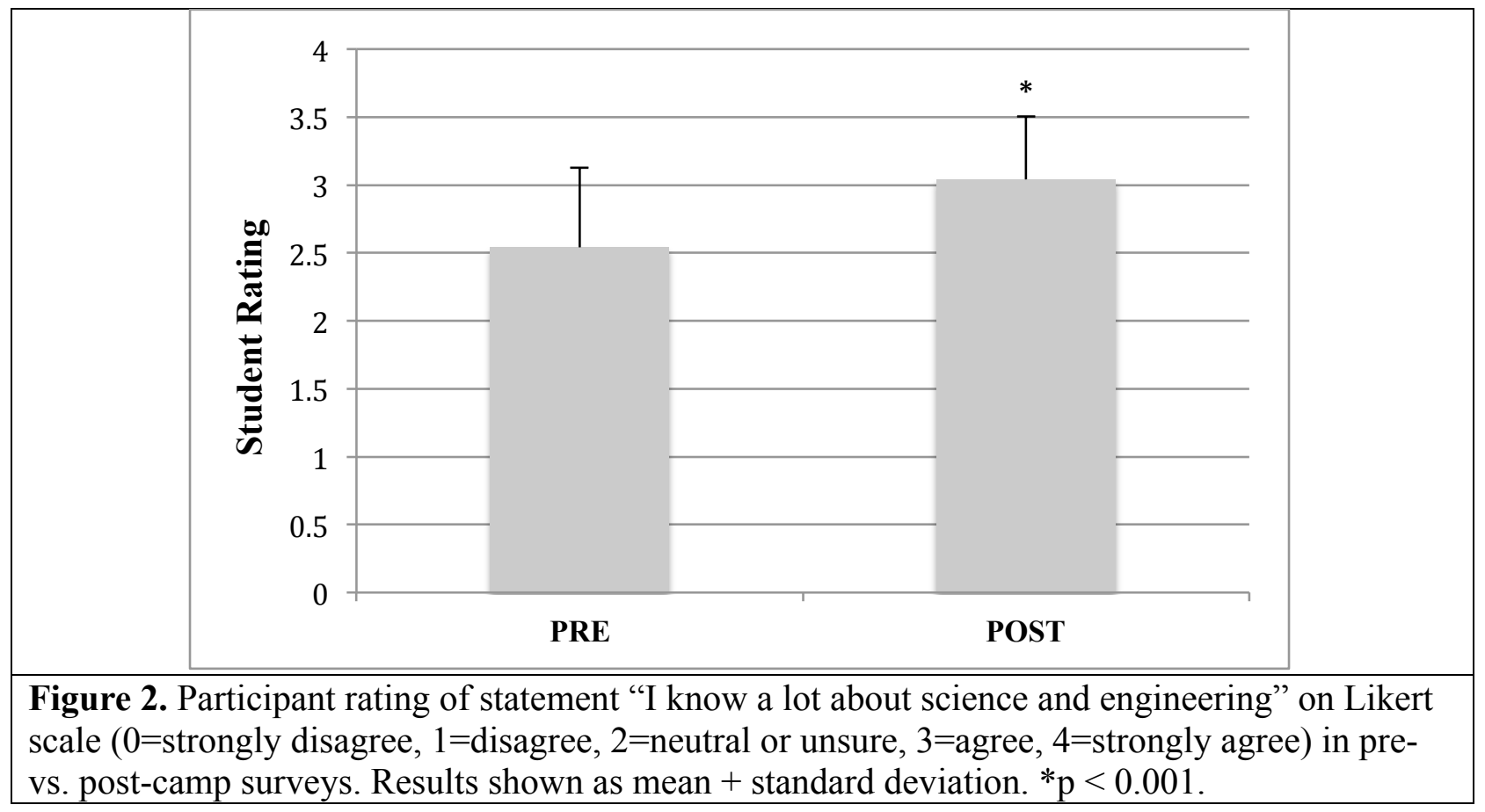

In addition, survey results indicate that the camp experience significantly increased the participants' desire to attend college at the host institution in the future $(\mathrm{p}=0.005)$ (Figure 3$)$.

Although not reaching statistical significance, student ratings in response to the statement "I am confident in my ability to design solutions to problems in bioengineering" increased after the camp, with 9/24 students rating their confidence at least one whole Likert number higher $(\mathrm{p}=0.067)$.

Similarly, the increase in scores in response to the statement "I am interested in a career in science or engineering" neared statistical significance $(p=0.078)$. We note that students rated their interest in a career in science or engineering as being already high in the pre-camp surveys (average rating $=3.5$ on a $0-4$ Likert scale). 


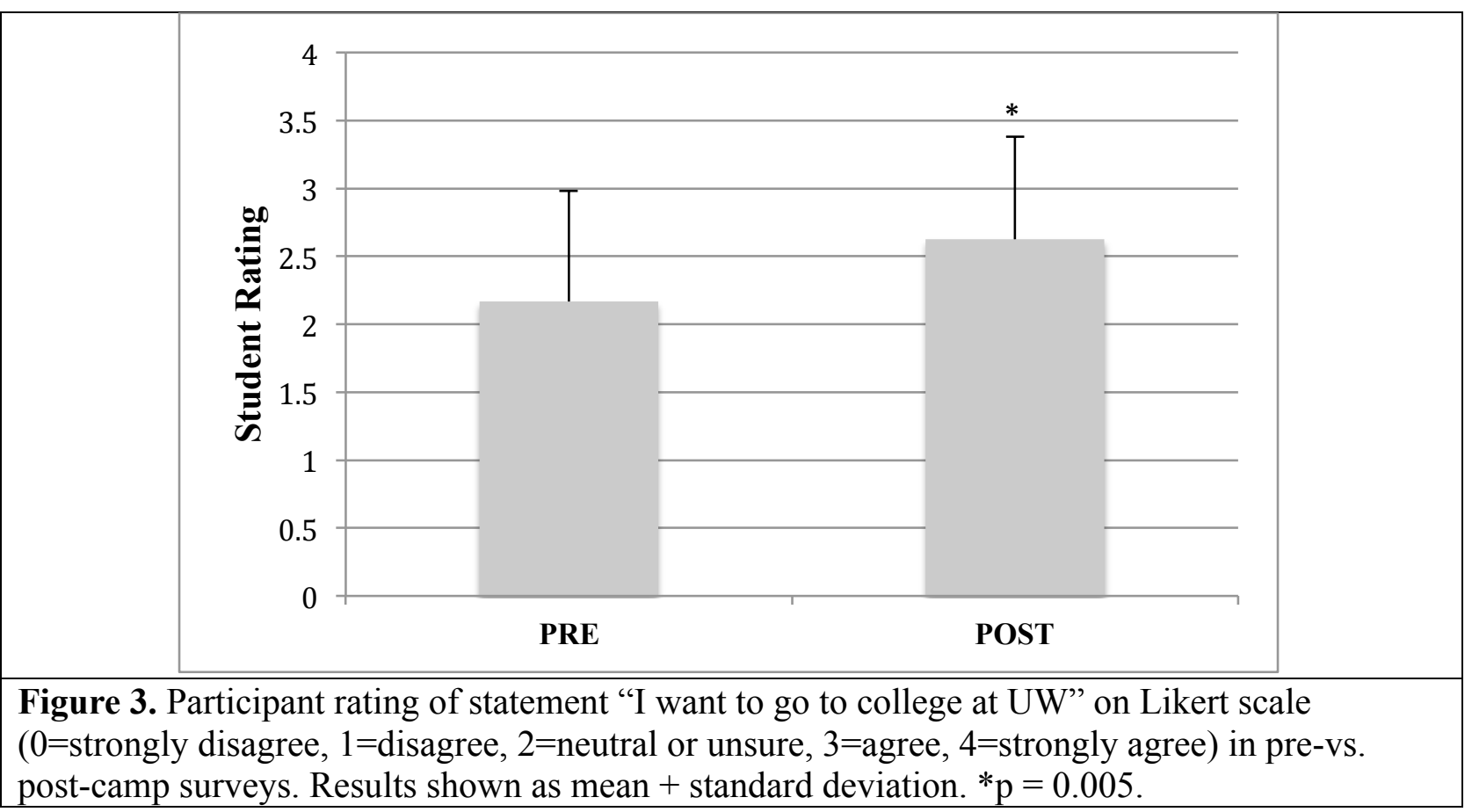

Overall, students reported very high interest in attending college. For the survey statement "I want to go to college," in the pre-camp survey, 23/24 students rated 4 (strongly agree) and one student responded 2 (neutral or unsure). In the post-camp survey, all 24 students rated 4 for this statement.

For the remaining 13 statements on the surveys (see Appendices), there was no significant change in student ratings in pre- vs. post-camp results.

\section{Qualitative Results}

Overall success of the camp was assessed via comments written in response to additional questions on the post-camp survey. Participants seemed well-pleased with the camp and the overall experience. For example, in response to the question "Were the instructors at BIOE camp knowledgeable, helpful, organized, and enthusiastic?" 24/24 students indicated yes, and the responses were noticeably positive. Representative quotations include:

Yes! They were so inspiring and open to telling us ways to succeed.

Yes, all instructors were very knowledgeable and really care about the camp.

Yes, very helpful and great! Learned a lot!

Yes, they were awesome.

Yes, they were, and were keen on providing us with bountiful information on the topic of BIOE

Yes, and they were always available to help.

Incredibly!

Yes, I learned a huge amount of things and also had fun. 
The variety of activities seemed to be a positive aspect of the camp. When asked "What did you like most about BIOE camp?" the wide range of responses indicates that our program design ensured we were able to engage students with a variety of preferences, learning styles, and priorities. Students had a large amount of positive commentary, including that they enjoyed most:

The people and the engineering activities All of the lab tours and experiences in the labs, especially activities All of the opportunities that were provided to me/us! I loved meeting smart, funny people. Meeting the professors and lab students Learning things that I would've had to wait until later in high school to learn The hands-on experiments and experience were great I liked learning new things as well as looking through other college students daily lives at college [sic]

I loved learning about BIOE and working with the other campers.

The HIV models where our job was to find places in the process to target with drugs. I liked the bioengineering "simulations", times where we could be creative and come up with our own solutions to problems. The lab tours were very interesting also.

I liked the activities where we figured out solutions to world problems.

All of the note-taking/lecture style "classes"

Learning all about the solutions to global health problems with the help of bioengineering

The little projects we did and the big project

I liked making presentations on what interested us and designing a solution.

Towards our efforts of continual improvement, we were interested in gathering data regarding what aspects of the camp students liked least and what they thought could be improved. Key suggestions included adding a tutorial early-on about antibodies and antigens and other biologyrelated information, since this is a theme throughout the camp and some students are unfamiliar with biology concepts. Numerous students expressed the desire to have additional experience with lab-related activities and hands-on experiments. Although every module included hands-on activities or experiments, the success of this type of learning activity was evident from several student comments.

\section{Discussion}

We designed and implemented a bioengineering summer day camp for high school students. Our program had four features that made it unique:

1) The curriculum was explicitly designed around a global health theme.

2) The curriculum was project-based.

3) Our program encouraged the development of scientific communication skills.

4) In addition to the core instructors, students had opportunities for meaningful interactions with several faculty members and undergraduate/graduate students throughout the program.

We chose global health as the theme for our curriculum because global health is an intriguing topic that appeals to students from diverse backgrounds and is accessible to students with 
variable previous exposure to science and engineering topics. In addition, applications in global health demonstrate bioengineering design principles in a manner that is easily understood by high school students. Finally, the research interests of the department of bioengineering at UW and the proximity of our campus to the Gates Foundation allowed us to provide students in our program several in-depth opportunities to learn about innovations in global health research.

In our project-based curriculum, students solved problems and designed solutions in small groups. For the culminating end-of-camp project, small groups of students identified needs in global health and designed bioengineering solutions. In addition to these formal presentations, our program gave students many opportunities to develop their scientific communication skills, as groups gave short, informal oral presentations to share their design solutions for each project throughout the week. Qualitative feedback from students indicates that the team project-based activities were very engaging.

The instructional model of our program (core instructors and guest instructors) allowed students to have meaningful interactions with several faculty members and numerous undergraduate/graduate students at UW. Guest instructors gave short lectures, facilitated handson activities, gave demonstrations, and hosted lab tours. The guest instructors helped keep students interested and allowed students to interact with people at different career stages. The guest instructors provided first-hand knowledge of cutting-edge research and expertise. Participants of the camp had many opportunities to discuss the college experience at UW with undergraduates through informal conversations during lunch breaks and the undergraduate question/answer session. This model of instruction is transferable to any program, and offers the benefit of highlighting the specific expertise of any department.

As this is the first implementation of our program, we focused our assessment efforts on program improvement. Student feedback indicates that the camp was successful in meeting most of its objectives. Quantitative data from the student surveys indicates that the program was successful in increasing students' self-assessed knowledge about science and engineering and the bioengineering field. In addition, students reported a significant increase in interest in attending the host institution in the future. Although not reaching statistical significance, student ratings increased in regard to confidence in designing solutions to problems in bioengineering and interest in a career in science or engineering. For longitudinal assessment of the impact of our program, we plan to survey camp alumni to track matriculation and intended major in college.

In the qualitative feedback from student surveys, several participants specifically mentioned that they enjoyed working in teams and finding solutions through project work. In addition, several participants noted that they enjoyed learning more about the college experience and meeting undergraduates through the program.

This was the initial offering of the bioengineering summer camp as a project-based curriculum with a focus on global health. (Previously, the department offered a camp based on cardiovascular health.) In future offerings, we will add content suggested by participants of the first offering of the camp, including an introductory module about antibodies and antigens and tours of more research labs. Learning modules and activities will be modified for future offerings depending on the expertise of instructors. 
In the future, we will seek to recruit more participants from diverse backgrounds in our program. Although more than half of the participants were female, few participants were from socioeconomic groups that are under-represented in science and engineering disciplines (including students who are the first in their families to attend college). In addition, only three participants requested and qualified for full-tuition scholarships. Thus, we are modifying our recruitment efforts for future offerings of the program. We are specifically targeting local schools with high percentages of students who are eligible for free/reduced meals according to the household financial criteria of the Seattle/King County Public School System. We plan to directly contact teachers from such schools who wrote letters of recommendation for previous applicants to our program, and ask them to mention our program to interested students. In addition to mailing letters and flyers to local schools, we have designed a full-color informational pamphlet with photos from the first offering of the camp that we will distribute at outreach events where program staff volunteer, and we have asked our departmental outreach group to distribute these during their activities. Furthermore, we have contacted other outreach groups at UW to learn about their recruitment strategies.

For the initial offering of the camp, the most effective recruiting tool was distributing flyers and speaking to prospective participants (and their parents, if present) at large events sponsored by UW. Several members of the camp staff volunteered at a two-day UW College of Engineering event in April 2014 that was open to the community and was attended by many local school groups. This was an especially effective recruitment tool, as several applicants stated that they learned about the camp from this event.

In conclusion, in this paper we provide information on the design and implementation of a bioengineering summer camp for high school students. Although the global health focus is an essential part of our program, many aspects of the curriculum and program logistics can be applied to other programs. The best practices established in our program can benefit other groups involved in bioengineering education for high school and early undergraduate students.

\section{Acknowledgements:}

We thank assistant instructor Ross Jones for his enthusiasm in teaching and help in designing the curriculum. We thank Dan Ratner, Dorian Varga, Josh Lee, and Kelli Jayn Nichols for their guidance in preparing this program and assistance with various camp activities. We are especially grateful to the following for their contributions to the learning modules: Kim Woodrow and members of the Woodrow lab, Suzie Pun, Barry Lutz, Rahil Jain, and Ian Andrews.

\section{Bibliography}

1. Yilmaz, M., Garcia, C., Guillen, T. \& Ramirez, D. (2011). A K-12 Advanced Research Camp for Engineering and Science Disciplines. American Society for Engineering Education (ASEE) Conference 2011, Vancouver, Canada, 2011. 
2. Yilmaz, M., Ren, J., Ramirez, D., Custer, S. \& Coleman, J. (2010). An Improved K-12 Outreach Camp for Engineering Disciplines. American Society for Engineering Education (ASEE) Conference 2010, Louisville, KY, USA, 2010.

3. Williams, D., Ma, Y., Prejean, L., Ford, M. J. \& Lai, G. (2007). Acquisition of Physics Content Knowledge and Scientific Inquiry Skills in a Robotics Summer Camp. Journal of Research on Technology in Education 40, 2007.

4. Rousche, P., Cho, M., Dai, Y., Hetling, J., Lu, H., Liang, J., McCormick, S., Schneeweis, D. \& Magin, R. (2006). A BioEngineering Summer Day Camp for High-School Science Students and Teachers. American Society for Engineering Education (ASEE) Conference 2006, Chicago, Illinois, USA, 2006.

5. Cezeaux, J., Rust, M. J., Gettens, R. \& Beach, R. D. (2011). Implementation of a Biomedical Engineering Summer Program for High School Students. American Society for Engineering Education (ASEE) Conference 2011, Vancouver, Canada, 2011.

6. Pittsburgh, U. o. (2014). Tissue Engineering Summer Camp. (Pittsburgh, U. o.,ed).

7. (2014). Biomedical Engineering: Physical Effects on Cells. (University, C.,ed).

8. (2014). Rice 360 Institute for Global Health Technologies. (University, R.,ed).

9. (2014). USC Summer Programs for High School Students. (California, U. o. S.,ed).

10. Sciences, N. A. o. (2008). Changing the Conversation: Messages for Improving Public Understanding of Engineering The National Academies Press, Washington, D.C. 


\section{Appendix 1: Pre-Program Survey}

The purpose of this survey is to obtain information about your experience at the Bioengineering Summer Camp. Survey results will be used to evaluate the program, and results may be shared for educational purposes only.

- This survey is voluntary. Choosing not to complete the survey will not affect your participation in the camp.

- Your responses are anonymous and will not be reviewed until after the camp.

\begin{tabular}{|c|c|c|c|c|c|}
\hline & $\begin{array}{l}\text { Strongly } \\
\text { Agree }\end{array}$ & Agree & $\begin{array}{l}\text { Neutral } \\
\text { or } \\
\text { Unsure }\end{array}$ & Disagree & $\begin{array}{l}\text { Strongly } \\
\text { disagree }\end{array}$ \\
\hline I am interested in science and engineering in general & 4 & 3 & 2 & 1 & 0 \\
\hline I am interested in the field of bioengineering & 4 & 3 & 2 & 1 & 0 \\
\hline $\begin{array}{l}\text { In high school, I would like to take more classes in } \\
\text { science and engineering }\end{array}$ & 4 & 3 & 2 & 1 & 0 \\
\hline $\begin{array}{l}\text { I would like to learn about other opportunities to learn } \\
\text { more about science and engineering }\end{array}$ & 4 & 3 & 2 & 1 & 0 \\
\hline I know a lot about science and engineering & 4 & 3 & 2 & 1 & 0 \\
\hline I know a lot about the field of bioengineering & 4 & 3 & 2 & 1 & 0 \\
\hline I am excited about bioengineering & 4 & 3 & 2 & 1 & 0 \\
\hline $\begin{array}{l}\text { I am confident in my ability to design solutions to } \\
\text { problems in bioengineering }\end{array}$ & 4 & 3 & 2 & 1 & 0 \\
\hline $\begin{array}{l}\text { I am confident in my ability to perform laboratory } \\
\text { work in bioengineering }\end{array}$ & 4 & 3 & 2 & 1 & 0 \\
\hline I want to go to college & 4 & 3 & 2 & 1 & 0 \\
\hline I am confident that I will succeed in college & 4 & 3 & 2 & 1 & 0 \\
\hline I want to go to college at UW & 4 & 3 & 2 & 1 & 0 \\
\hline I want to be a bioengineering major at UW & 4 & 3 & 2 & 1 & 0 \\
\hline I want to study science or engineering in college & 4 & 3 & 2 & 1 & 0 \\
\hline I am interested in a career in science or engineering & 4 & 3 & 2 & 1 & 0 \\
\hline I am confident that I will be successful in my career & 4 & 3 & 2 & 1 & 0 \\
\hline
\end{tabular}


BIOENGINEERING CAMP 2014 PRE-PROGRAM SURVEY (continued)

Please check the reason(s) that you are attending BIOE Summer Camp at UW: (check all that apply)

Learn bioengineering concepts

Obtain lab experience in bioengineering

Overall educational experience in science and engineering

Find out what UW is like

Find out what college is like

Meet college students and professors

Gain confidence in my ability to apply for college

Gain confidence in my ability to succeed in college

Make parents happy

Look good my resume

Other reason - please describe in the space below

What is a major challenge for you in applying for college?

What is the primary language spoken in your home?

Please describe yourself: (check all that apply)

Starting $9^{\text {th }}$ grade this year

Starting $10^{\text {th }}$ grade this year

Female

Male

Member(s) of family has/have attended college

White, non-Hispanic/Latino

Hispanic/Latino

Native American/Alaska Native

Asian American

African American

Native Hawaiian/Other Pacific Islander Other

THANK YOU FOR COMPLETING THIS SURVEY! 


\section{Appendix 2: Post-Program Survey}

The purpose of this survey is to obtain information about your experience at the Bioengineering Summer Camp. Survey results will be used to evaluate the program, and results may be shared for educational purposes only.

- This survey is voluntary. Choosing not to complete the survey will not affect your participation in the camp.

- Your responses are anonymous and will not be reviewed until after the camp.

\begin{tabular}{|c|c|c|c|c|c|}
\hline & $\begin{array}{l}\text { Strongly } \\
\text { Agree }\end{array}$ & Agree & $\begin{array}{l}\text { Neutral } \\
\text { or } \\
\text { Unsure }\end{array}$ & Disagree & $\begin{array}{l}\text { Strongly } \\
\text { disagree }\end{array}$ \\
\hline I am interested in science and engineering in general & 4 & 3 & 2 & 1 & 0 \\
\hline I am interested in the field of bioengineering & 4 & 3 & 2 & 1 & 0 \\
\hline $\begin{array}{l}\text { In high school, I would like to take more classes in } \\
\text { science and engineering }\end{array}$ & 4 & 3 & 2 & 1 & 0 \\
\hline $\begin{array}{l}\text { I would like to learn about other opportunities to learn } \\
\text { more about science and engineering }\end{array}$ & 4 & 3 & 2 & 1 & 0 \\
\hline I know a lot about science and engineering & 4 & 3 & 2 & 1 & 0 \\
\hline I know a lot about the field of bioengineering & 4 & 3 & 2 & 1 & 0 \\
\hline I am excited about bioengineering & 4 & 3 & 2 & 1 & 0 \\
\hline $\begin{array}{l}\text { I am confident in my ability to design solutions to } \\
\text { problems in bioengineering }\end{array}$ & 4 & 3 & 2 & 1 & 0 \\
\hline $\begin{array}{l}\text { I am confident in my ability to perform laboratory } \\
\text { work in bioengineering }\end{array}$ & 4 & 3 & 2 & 1 & 0 \\
\hline I want to go to college & 4 & 3 & 2 & 1 & 0 \\
\hline I am confident that I will succeed in college & 4 & 3 & 2 & 1 & 0 \\
\hline I want to go to college at UW & 4 & 3 & 2 & 1 & 0 \\
\hline I want to be a bioengineering major at UW & 4 & 3 & 2 & 1 & 0 \\
\hline I want to study science or engineering in college & 4 & 3 & 2 & 1 & 0 \\
\hline I am interested in a career in science or engineering & 4 & 3 & 2 & 1 & 0 \\
\hline I am confident that I will be successful in my career & 4 & 3 & 2 & 1 & 0 \\
\hline
\end{tabular}


BIOENGINEERING CAMP 2014 POST-PROGRAM SURVEY (continued)

Were the instructors at BIOE camp knowledgeable, helpful, organized, and enthusiastic?

What did you like the MOST about BIOE camp?

What did you like the LEAST about BIOE camp?

Can you think of any topics or activities that should be added to BIOE camp?

If you have any additional comments about BIOE camp, please write them below:

THANK YOU FOR COMPLETING THIS SURVEY!

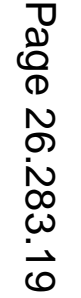

